\title{
Highlights of the issue
}

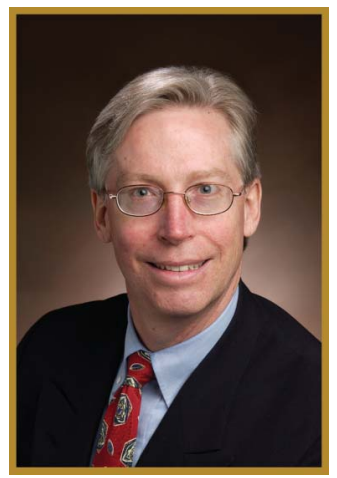

7 his issue of Neurology: Clinical Practice features a provocative article from Torres et al. (p. 279) summarizing a survey of college athletes' attitudes about

Leporting concussion. While most responders had been educated about concussive symptoms and their significance, almost half who had experienced a concussion knowingly hid symptoms to remain in a game. An accompanying editorial by Drs. Hainline, Dexter, and DiFiori discusses the implications and offers concrete actions neurologists can take to address this concern (p. 277).

Drs. Klein and Bourdette discuss when, why, and how to report adverse events with drugs and devices (p. 288). In a multivariate analysis of prognostic factors related to death in patients with amyotrophic lateral sclerosis, Traxinger et al. report that age, body mass index, and forced vital capacity measured at the first clinic visit were independent prognostic indicators of survival (p. 313). We welcome your feedback.

Finally, a reader brought to our attention that in a recent issue we used a picture of illegal drugs and money that was recognizable as coming from a specific country ("Neurotoxicology: Five New Things" Neurol Clin Pract 2012;2:301-309). The authors were not responsible for the choice of this image. We did not intend to offend any person, group, or country, and apologize for any unhappiness this may have caused. In the electronic versions of the article, the money has been altered in such a way as to eliminate obvious recognition of the country of origin. We will continue to do our best to place helpful, meaningful pictures within our articles, and be as attentive to the appropriateness of pictures as we are to the text.

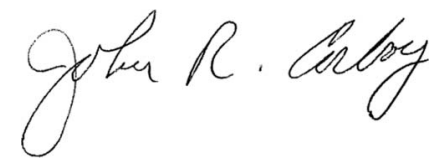

John R. Corboy, MD, FAAN

CORRECTION

Teriflunomide

In the article "Teriflunomide" by J. Oh and P.W. O'Connor (Neurology ${ }^{\circledR}$ Clinical Practice 2013;3: 254-260), there is an error in the text on page 258. The last sentence in the second paragraph should read "...and confirm that the plasma level is $<0.02 \mathrm{mg} / \mathrm{L} .{ }^{13}$ " The authors regret the error. 


\title{
Neurology ${ }^{\circ}$ Clinical Practice
}

\author{
Highlights of the issue \\ Neurol Clin Pract 2013;3;275 \\ DOI 10.1212/CPJ.0b013e3182a2ee5c
}

This information is current as of August 19, 2013

\section{Updated Information \& Services}

Permissions \& Licensing

Reprints including high resolution figures, can be found at:

http://cp.neurology.org/content/3/4/275.1.full.html

Information about reproducing this article in parts (figures,tables) or in its entirety can be found online at:

http://cp.neurology.org/misc/about.xhtml\#permissions

Information about ordering reprints can be found online: http://cp.neurology.org/misc/addir.xhtml\#reprintsus

Neurol Clin Pract is an official journal of the American Academy of Neurology. Published continuously since 2011, it is now a bimonthly with 6 issues per year. Copyright ( 2013 American Academy of Neurology. All rights reserved. Print ISSN: 2163-0402. Online ISSN: 2163-0933.

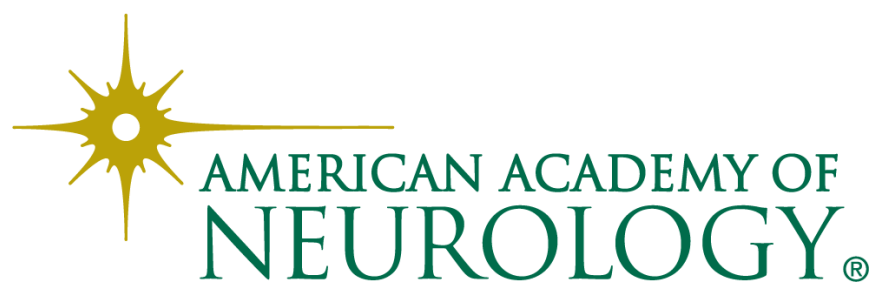

